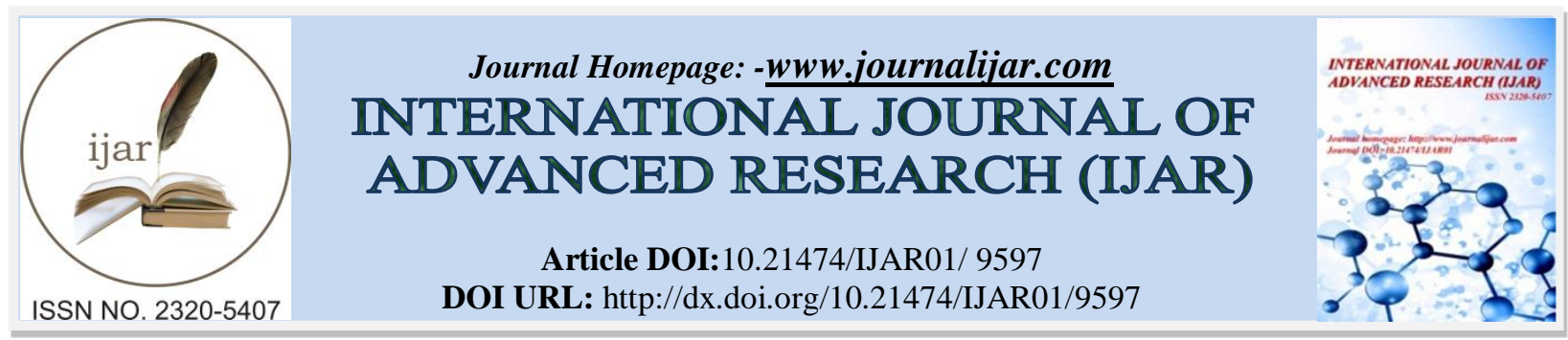

RESEARCH ARTICLE

\title{
STUDY OF SELECTION OF PV MODULE MATERIAL AND THEIR PERFORMANCE ON DIFFERENT CLIMATIC CONDITION: A REVIEW.
}

Ravi Shankar yadav and Sunil Kumar Chaturvedi.

Department of Mechanical Engineering, NRI Institute of Research and Technical, Bhopal (M.P), INDIA.

\section{Manuscript Info}

Manuscript History

Received: 20 June 2019

Final Accepted: 22 July 2019

Published: August 2019

Key words:-

PV cells, Selection of materials, Exergy, Efficiency \& Power generation, Variable temperature, climate change.

\begin{abstract}
With the growing population, and increasing of pollution at a faster rate by using conventional source of energy leads to global warming, natural hazards, access earth mining worldwide and demand of energy at low cost focusing the researcher to substitute the renewable energy system to meet the requirement of energy consumption has reached to peak level worldwide and hence Solar energy is becoming one of the important energy in the future as a great renewable energy source. However the cost of electricity from solar PV cells is still several times higher than the conventional power generation. So it is very necessary to improve the efficiency of the solar PV cells. It is necessary to have that source available easily and in sufficient quantity so that with the diminishing non renewable source basic need of energy can be fulfilled. This source can be the all time available source. In this paper, it is seeking into the tremendous progress made in recent years on a photovoltaic (PV) cells materials, geometrical shapes and devices in terms of their conversion efficiencies. Solar cells vary its performance under temperature changes or it can say that on climate change because temperature is variable with respect to climatic change, as climate condition is also variable with seasonal change (i.e. summer, rainy and winter) even hours to hours, and day to day. Change in temperature affects its power generation. The rapid development of solar PV cells has created challenging environment in the future. Efficiency can be increased either by changing PV material, concentrating solar rays or using solar tracking system. This paper deal with a brief overview of the recent progress in PV cell efficiencies, exergy and power generation based on different climatic condition and on the selection of good quality materials and devices so that maximum sun heat can absorbed and power conversion takes place.
\end{abstract}

Copy Right, IJAR, 2019,. All rights reserved.

\section{Introduction:-}

India is a rapidly growing economy with more than 1 billion population about $17.5 \%$ world population, is facing a huge energy demands. India stands fifth in the world in the production and consumption of electricity. The power produced in India is mostly from coal (53\%) and it is predicted that country's coal reserved won't last beyond 204050. More than $72 \%$ population is living in villages and about half of the villages remain without electricity. Its peak

Corresponding Author:-Ravi Shankar yadav.

Address:-Department of Mechanical Engineering, NRI Institute of Research and Technical, Bhopal (M.P), INDIA. 
time that our country should concentrate more on energy efficiency, conservation and renewable energy such as wind farm, bio-mass, tidal, geothermal, solar energy etc. to meet the uncertain demand, solar energy is the best form of energy which can fulfill the needs of energy in an India and bridge the energy demand -supply gap.

\section{Solar Energy in India}

India has tremendous scope of generating solar energy. The geographical location of the country stands to its benefit for generating solar energy. The reason being India is a tropical country and it receives solar radiation almost throughout the year, which amounts to 3,000 hours of sunshine. This is equal to more than 5,000 trillion $\mathrm{kWh}$. Almost all parts of India receive 4-7 $\mathrm{kWh}$ of solar radiation per sq meters. This is equivalent to 2,300-3,200 sunshine hours per year. States like Andhra Pradesh, Bihar, Gujarat, Haryana, Madhya Pradesh, Maharashtra, Orissa, Punjab, Rajasthan, and West Bengal have great potential for tapping solar energy due to their location. Since majority of the population lives in rural areas, there is much scope for solar energy being promoted in these areas. Use of solar energy can reduce the use of firewood and dung cakes by rural household.

Why solar energy should be preferred: -

It is well known that conventional source (Fossil fuels) of energy has many disadvantages that are leads to pollution, uncertain climate change, global warming and more over it will be exhausted in few years. So keeping in mind the great gift given by the god to the entire universe the following advantages of solar

\section{Clean Energy Source:}

Solar panels give off no contamination; the main contamination that occurs as a consequence of solar panels is the assembling of these gadgets in industrial facilities, the transportation of the merchandise, and the installation. That means, once they're actually installed on your home, they are doing absolutely nothing negative to the atmosphere; this is a huge difference than what you see from other forms of standard energy.

\section{Renewable and Sustainable:}

Solar energy is a renewable source of energy which means we cannot run out of it. Unlike fossil fuels that will expire in another few decades solar energy is never going to expire. We will continue to get solar energy as long as sun is there. Another pro of solar energy is that it is sustainable. Sustainable simply means to be able to meet the needs of the present without compromising the needs of the future generations. Sun is going to last for another 6.5 billion years, according to NASA and there is no way that we could over consume it.

\section{Power Remote Areas:}

One of the incredible benefits of solar energy is the capability to bridle power in remote areas that are not necessarily connected to a national electrical matrix. A prime example of this is in space, where satellites are controlled by high productivity solar cells. The establishment of solar panels in remote areas is normally substantially more financially savvy than laying the high voltage wires that are necessary to provide these areas with electricity. Solar energy might be extremely productive in an expansive region of the globe, and new innovations take into account a more effective energy generation on cloudy/dull days.

\section{Can be Installed on Rooftops:}

Solar panels might be installed on any number of roofs, which wipes out the issue of trying to find enough space for solar panel arrangement. Not only does it save you space, but it can also end up saving you and your family a lot of money as well. Even though the installation cost of solar panels can be quite high, depending on how large they are and other factors (we will talk more about this in the "cons"), they give a free supply of power, which means that they will eventually pay for themselves in the long run.

\section{Reduce Electricity Bills:}

The utilization of solar energy to create power allows you and your family to be free of the limitations of fossil fuels that could negatively affect the power that your home is able to use on a regular basis. Getting your solar panels financed can help you to eliminate upfront cost that you might have to pay from your own pocket. Moreover, homeowners can sell surplus electricity generated to utility companies to reduce their monthly electricity bill. 


\section{Availability:}

Sunlight is available throughout the world and can easily be harnessed by every nation. The only drawback is that it can only be harnessed during daytime. It is estimated that the world's oil reserves will last for about 50-60 years, whereas sunlight is available forever and can be utilized till the end of this planet.

\section{Low Maintenance:}

Modern solar panels require less maintenance as they don't involve any moving parts and last for about 20-25 years. They require few meters of space for residential use and require cleaning a few times a year.

\section{Silent:}

The creation of energy from the use of fossil fuels and other renewable energy sources (e.g. wind turbines) might be incredibly noisy, yet solar energy produces power quietly. That way, you won't have to worry about adding sound pollution to the area that you live in either, which will make it that much more pleasant for your family and those who live around you. They operate silently and are therefore favored by many people.

\section{About the solar panel and selection of materials:-}

Given that sunlight can be used differently whether on Earth or in space points to the fact that location, itself, is a significant factor when it comes to choosing one of the types of solar panels over another. Distinguishing between different types of solar panels often means differentiating between single-junctions and multijunctions solar panels - or first, second, or third generations. Single-junction and multi-junctions differ in the number of layers on the solar panel that will observe the sunlight, whereas the classification by generation focuses on the materials and efficiency of the different types of solar panels.

\section{1st Generation Solar Panels}

These are the traditional types of solar panels made of mono crystalline silicon or poly silicon and are most commonly used in conventional surroundings. This type of solar panels (made of monocrystalline silicon) is the purest one. You can easily recognize them from the uniform dark look and the rounded edges. The silicon's high purity causes this type of solar panel has one of the highest efficiency rates, with the newest ones reaching above 20\%. Monocrystalline panels have a high power output, occupy less space, and last the longest. Of course, that also means they are the most expensive of the bunch. Another advantage to consider is that they tend to be slightly less affected by high temperatures compared to polycrystalline panels.

Monocrystalline Solar panels:

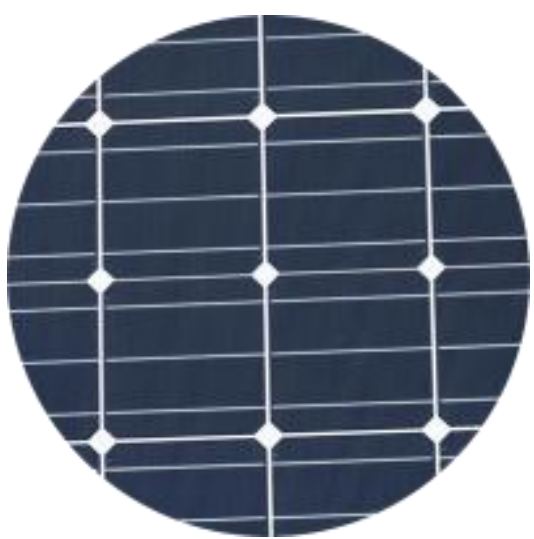

Fig 1:-Mono crystalline Solar Panels (Mono-SI)

Polycrystalline Solar Panels (Poly-SI):-

It is easy to distinguish these panels because this type of solar panels has squares, its angles are not cut, and it has a blue, speckled look. They are made by melting raw silicon, which is a faster and cheaper process than that used for monocrystalline panels. This leads to a lower final price but also lower efficiency (around 15\%), lower space efficiency, and a shorter lifespan since they are affected by hot temperatures to a greater degree. However, the differences between mono- and polycrystalline types of solar panels are not so significant and the choice will strongly depend on your specific situation. The first option offers slightly higher space efficiency at a slightly higher price but power outputs is basically the same. 


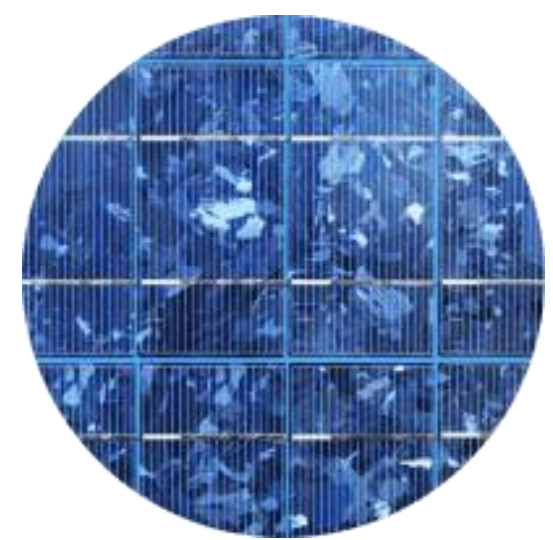

Fig 2:-Polycrystalline Solar Panels (Poly-SI)

2nd Generation Solar Panels Thin film solar cells:-

These cells are different types of thin film solar cells and are mainly used for photovoltaic power stations, integrated in buildings or smaller solar power systems. If you are looking for a less expensive option, you might want to look into thin-film. Thin-film solar panels are manufactured by placing one or more films of photovoltaic material (such as silicon, cadmium or copper) onto a substrate. These types of solar panels are the easiest to produce and economies of scale make them cheaper than the alternatives due to less material being needed for its production.

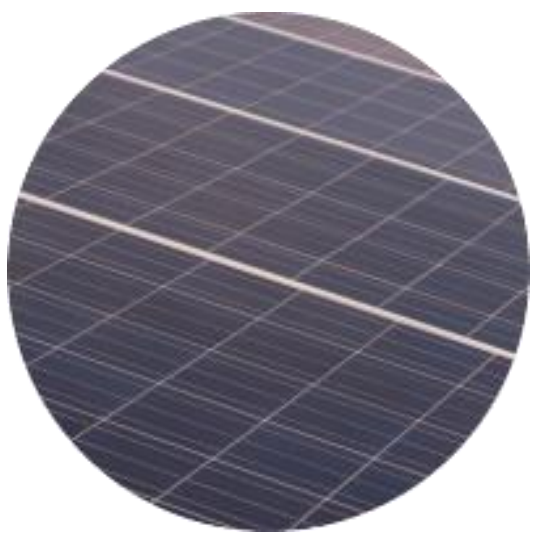

Fig 3:-Thin film solar cells (TFSC)

\section{Amorphous Silicon Solar Cell (A-Si):-}

The amorphous silicon solar cell is among the different types of solar panels, the one that is used mainly in such pocket calculators. This type of solar panel uses a triple layered technology, which is the best of the thin film variety. Just to give a brief impression of what "thin" means, in this case, we're talking about a thickness of one micrometer (one millionth of a meter). With only $7 \%$ efficiency rate, these cells are less effective than crystalline silicon ones that have efficiency rate of circa $18 \%$ but the advantage is the fact that the A-Si-Cells are relatively low in cost.

3rd Generation Solar Panels 3rd generation solar panels include a variety of thin film technologies but most of them are still in the research or development phase. Some of them generate electricity by using organic materials, others use inorganic substances (CdTe for instance)

\section{Biohybrid Solar Cell:-}

The Biohybrid solar cell is one of the types of solar panels that is still in the research phase. It has been discovered by an expert team at Vanderbilt University. The idea behind the new technology is to take advantage of the photo system and thus emulate the natural process of photosynthesis. Many of the materials being used in this cell are similar to the traditional methods, but only by combining the multiple layers of photo system 1 , the conversion from 
chemical to electrical energy becomes much more effective (up to 1000 times more efficient than 1st generation types of solar panels).

\section{Cadmium Telluride Solar Cell (CdTe):-}

Among the collection of different types of solar panels, this photovoltaic technique uses Cadmium Telluride, which enables the production of solar cells at relatively low cost and thus a shorter payback time (less than a year). Of all solar energy technologies, this is the one requiring the least amount of water for production. Keeping the short energy payback time in mind, CdTe solar cells will keep your carbon footprint as low as possible. The only disadvantage of using Cadmium Telluride is its characteristic of being toxic, if ingested or inhaled. In Europe especially, this is one of the greatest barriers to overcome, as many people are very concerned about using the technology behind this type of solar panel.

\section{Concentrated PV Cell (CVP and HCVP):-}

Concentrated PV cells generate electrical energy just as conventional photovoltaic systems do. Those multijunction types of solar panels have an efficiency rate up to $41 \%$, which, among all photovoltaic systems, is the highest so far.

\section{A Glance of Solar Cell: -}

Different types of solar panels serve different needs and purposes. For a quick and general overview based on efficiency rate has put together which helps to provide the useful information regarding the most common type solar panel.

Table no1:-Types of Solar cell

\begin{tabular}{|l|l|l|l|}
\hline Type of Solar Cell & $\begin{array}{l}\text { Efficiency- } \\
\text { Rate }\end{array}$ & Advantages & Disadvantages \\
\hline $\begin{array}{l}\text { Monocrystalline Solar } \\
\text { Panels (Mono-SI) }\end{array}$ & $\sim 20 \%$ & $\begin{array}{l}\text { High efficiency rate; optimized } \\
\text { for commercial use; high life- } \\
\text { time value }\end{array}$ & Expensive \\
\hline $\begin{array}{l}\text { Polycrystalline Solar } \\
\text { Panels (p-Si) }\end{array}$ & $\sim 15 \%$ & Lower price & $\begin{array}{l}\text { Sensitive to high temperatures; } \\
\text { lower lifespan \& slightly less space } \\
\text { efficiency }\end{array}$ \\
\hline $\begin{array}{l}\text { Thin-Film: Amorphous } \\
\text { Silicon Solar Panels (A-SI) }\end{array}$ & $\sim 7-10 \%$ & $\begin{array}{l}\text { Relatively low costs; easy to } \\
\text { produce \& flexible }\end{array}$ & shorter warranties \& lifespan \\
\hline $\begin{array}{l}\text { Concentrated PV Cell } \\
\text { (CVP) }\end{array}$ & $\sim 41 \%$ & $\begin{array}{l}\text { Very high performance \& } \\
\text { efficiency rate }\end{array}$ & $\begin{array}{l}\text { Solar tracker \& cooling system } \\
\text { needed to reach high efficiency } \\
\text { rate) }\end{array}$ \\
\hline
\end{tabular}

\section{Objective of Research:-}

The primary objective of this paper is to study of photovoltaic (PV) solar cell research and development is to bring about increased efficient Photovoltaic Solar Cells, and the reduction in the cost of production by selecting better solar thermal material for different climatic condition and solar mechanism with the rotation of earth to a level that will be competitive with the conventional ways of generating power. To achieve this, there has to be a tremendous increase in the efficiency of Photovoltaic materials and devices. In recent years, leading progress has been made to improve the efficiency of almost all the leading Photovoltaic materials and devices due to climatic change.

\section{Literature Review}

1. Alcantara S.P., Del et.al. Solar photovoltaic (SPV) systems are a device which is directly convert solar radiation in the form of heat and electrical energy. Solar energy reaching on the earth surface can be utilized directly in two ways, firstly by converting directly electrical energy (electricity) through solar photovoltaic Modules secondly, by heating the medium by means of solar collectors for low temperature heating applications. Currently, most of solar photovoltaic (SPV) modules are based on crystalline silicon technology which is basically dived into three technologies viz. Mono-crystalline silicon (m-Si), multi-crystalline silicon (mc-Si) and ribbon silicon. In general it has been found that the mono-crystalline- silicon is more expensive than that of multi-crystalline-silicon and as far as the efficiency is concerned, so it is proved that $\mathrm{m}$-Si based module is better than that of mc-Si module. The single crystal silicon is made of a cylindrical ingot and the crystal lattice of the entire sample is continuous with no grain boundaries. On the other hand, the multicrystalline are made of square ingot and composed of multiple small silicon crystals 
2. Sahin et al. The thermodynamic characteristics of the solar photovoltaic (PV) cells using exergy analysis. They developed and applied the new approach for the assessment of PV cells and found that the presented approach was realistic as it accounts for thermodynamic quantities such as enthalpy and entropy. They also analyzed the PV cells on the basis of the energy and exergy efficiencies, the energy efficiency was found to be varying between $7-12 \%$ during the day while, the exergy efficiency was found to be varying between 2-8\% Investigated by.

3. Joshi et al. The performance characteristics of a photovoltaic (PV) and photovoltaic-thermal (PV/T) system using energy and exergy analysis for the New Delhi, India. They found that in the case of PV/T, the energy efficiency varies between $33-45 \%$, Iwhile the corresponding exergy efficiency varies between $11-16 \%$. On the other hand, for PV alone, the exergy efficiency was found to be varying in the range of 8-14\% for a typical set of operating parameters. They also calculated the fill factor in order to know the behavior of the exergy efficiency of the SPV systems and found that the higher the fill factor better would be the exergy efficiency .

4. K.N.Shukla et.al. The energy, exergy, and power conversion efficiencies of both the modules have been evaluated based on measured parameters such as solar intensity, ambient temperature, wind speed, and module temperature. Exergetic efficiency of amorphous PV module varied from $2.44 \%$ to $3.92 \%$ whereas it varied from $4.83 \%$ to $8.32 \%$ for polycrystalline PV module throughout the day. The energy efficiencies of both the modules are found to be always higher than that of exergy efficiencies and power conversion efficiencies.

5. M. R. Abdelkader et.al. This paper evaluates the performance of different solar modules in semi arid climate as in Jordanian. An experiment to investigate the performance of two photovoltaic modules is conducted at different times of the year. The measured parameters in this paper are: output open circuit voltage and short circuit current from the PV modules, ambient temperature and solar intensity. The relationship between the performance and the efficiency of mono-crystalline was reached $18 \%$ of PV module and multi crystalline PV module was reached $16 \%$ measured by experiment. The performance value of the PV solar module is identified and compared with the output values supplied by the producer of the PV modules and with other PV models .

6. T.T.Chow et.al. A review paper on photovoltaic/thermal hybrid solar technology .they give information about basic concepts, early work, technological development in the 1990s and performance assessment of PV system. They also give information about type of flat-plant PVT collector system and development of concentrator- type design reported in the last decade and miscellaneous and commercial development in the last decade.

7. Akash kumar shukla et. al.A review of exergetic assessment of BIPV module using parametric and photonic energy methods in this paper, a detailed review on energy and exergy analysis of building integrated photovoltaic module to evaluate the electrical performance, exergy destruction and exergy efficiency with photonic method has been discussed

8. Tiwari et. Al. Thermal modeling of photovoltaic (PV) modules and their applications. In the review article different applications of PV module based on electrical and thermal output has been covered. Also in that article they covered the detailed description and thermal model of PV and hybrid photovoltaic thermal (HPVT) systems, using water and air as the working fluid. The numerical modelling and analysis of thermal and electrical output of PV and HPVT in terms of an overall thermal energy and exergy has been carried out in this study. From their extensive literature review, they found that the photovoltaic-thermal (PVT) modules were very promising devices and there exists a lot of scope to further improve the performances. The CIGS solar cells in the BIPVT system are the most suitable from the energy payback time (EPBT) and energy production factor (EPF) point of view. However, mono-crystalline solar cells in the BIPVT system were found to be the most suitable from the life cycle conversion efficiency (LCCE) point of view.

9. Soteris A. Kalogirou et. al. This review paper presents the exergy analysis of solar thermal system. It also gives the information about various types of solar collectors and application of solar thermal systems. As solar collectors are an important technology when sustainability is considered, exergy analysis gives more information and representative performance evaluation, is a valuable method to evaluate and compare possible configurations of this performance evaluation.

10. S. Armstrong et. al. A thermal model for photovoltaic panels under varying atmospheric conditions and It is a interested to determined thermal response time of the PV panel. It is measurements the wind speed, global radiation, PV panel back surface temperature and ambient temperature are used to calculate the convective and radioactive heat loss from the panel. The predicted time constant values are compared to the measured time constant under the three different wind speeds.

11. Arvind Tiwari, et. al. Performance evaluation of solar photovoltaic/thermal systems and also analyzed to Exergy analysis of integrated photovoltaic thermal solar water heater under Constant flow rate and constant collection temperature modes. It is observed that the overall exergy efficiency indicating the optimum value of flow rate of $0.006 \mathrm{~kg} / \mathrm{s}$ as reported earlier. However, thermal efficiency increases significantly with increase of 
flow rate up to $0.006 \mathrm{~kg} / \mathrm{s}$ and then increase is marginal as expected. For comparison, the hourly variation of solar cell, back surface PV module, water temperature and solar cell efficiency has been evaluated.

12. Latifa Sabri et.al. In this study, an experimental research concerning the Effect of Ambient Conditions on Thermal Properties of Photovoltaic Cells: Crystalline and Amorphous Silicon The influence of cell temperature on the thermal characteristics such as the specific heat and thermal conductivity of the cell is show that specific heat increases exponentially by increasing the cell temperature, and also indicates the thermal conductivity decreases linearly for both crystalline and amorphous silicon.

13. Dubey et. al. Evaluated the energetic and exergetic performance of a PV/T air collector with air duct above the absorber plate and the one with air duct below the absorber plate it is found that the latter one gives batter results in terms of thermal energy, electrical energy and exergy gain.

14. K. Sudhakar et. al. analysis of Energy and exergy $36 \mathrm{~W}$ solar photovoltaic modules it is concluded that exergy is a more effective and more efficient tool for the performance analysis of the solar panel.

\section{Conclusions:-}

It seen from the above literature survey remarkable progress has been made by researchers in recent years in improving the conversion efficiencies on a number of PV cells by adopting different approach and better quality of thermal material at all the possible extent. Some exciting possibilities are emerging on new PV devices with moderate efficiencies and potential for lower cost

\section{Future scope of work}

1. Study can be conducted for further improvement of energy of solar module.

2. Effectiveness can be studied by developing low cost Semiconductor materials.

3. Study on minimizing losses of modules.

\section{References:-}

1. Rumani saikia phukan, Solar Energy in India - Pros, Cons and the Future related article, July 30, 2014.

2. Pandey, A. K., et al.: Energy and Exergy Performance Evaluation of a Typical Solar THERMAL SCIENCE: Year 2015, Vol. 19, Suppl. 2, pp. S625-S636.

3. M. R. Abdelkader, A. Al-Salaymeh, Z. Al-Hamamre, Firas Sharaf, A comparative Analysis of the Performance of Monocrystalline and Multiycrystalline PV Cells in Semi Arid Climate Conditions: the Case of Jordan, volume -4, number 5, November-2010 ISSN1995-6665 page 543-552.

4. P.Rawat, M.Debbarma, S.Mehrotra, K.Sudhakar, P. kumar sahu, Peformance Evaluation of solar photovoltaic/ Thermal hybrid water collector, impending power demand and innovative energy paths- ISBN: 978-93-8308384-8.

5. G.N.Tiwari, Swapnil Dubey, Book "Fundamental of Photovoltaic Modules and its Applications" 2009,P001P004.

6. http://www.nptel.ac.in/courses/112108148/pdf/Module_8.pdf

7. S.A.Kalogirou, Sotirios Karellas, V. Badescu, K.Braimakis, E nergy analysis on solar thermal system: A better understanding of their sustainability, Renewable Energy 85 (2016) 1328-1333.

8. T. T. Chow, G. Pei, K. F. Fong, Z. Lin, A. L. S. Chan, and J. Ji, "Energy and exergy analysis of photovoltaicthermal collector with and without glass cover," Applied Energy, vol. 86, no. 3, pp. 310-316, 2009.

9. K. Sudhakar and Tulika Srivastava, Energy and exergy analysis of $36 \mathrm{~W}$ solar photovoltaic module, International Journal of Ambient Energy, 2013

10. Wong, K. F. V. 2000. Thermodynamics for Engineers. University of Miami, Boca Raton, Fla, USA: CRC Press LLC.

11. K.N. Shukla*, Saroj Rangnekar and K. Sudhakar, A comparative study of exergetic performance of amorphous and polycrystalline solar PV modules, int.J. Exergy 17 (4) (2015) 433-455,

12. Bejan, A. (1982) Entropy Generation through Heat and Fluid Flow, John Wiley and Sons,Chichester, UK.

13. Bejan, A. (1998) Advanced Engineering Thermodynamics, John Wiley and Sons, Chichester, UK.

14. S.Farahat, F.Sarahaddi,H.Ajam, Exergetic optimization of flate solar collectors, renew.energy 34(4) (2009) $1169-1174$.

15. R.Petela, Exergy of undiluted thermal radiation, solar energy 74 (2003) 469-488

16. Akash kumar shukla, k.sudhakar, Prashant baredar, Exergetic assessment of BIPV module using parametric and photonic energy methods: A review, Energy and Buildings 119 (2016) 62-73. 
17. Himsar Ambarita, Hideki Kawai, Experimental study on solar-powered adsorption refrigeration cycle with activated alumina and activatecarbon as adsorbent, Case Studies in Thermal Engineering 7 (2016) 36-46.

18. S. Armstrong, W.G. Hurley, A thermal model for photovoltaic panels under varying atmospheric conditions. Applied Thermal Engineering 30 (2010) 1488e1495.

19. Watmuff, J. H., W. W. S. Charters, and D. Proctor. 1977. Solar and wind induced external coefficients for solar collectors. Cooperation Mediterraneenne pour l'Energie Solaire,Revue Internationale d'Heliotechnique, 2nd Quarter. p. 56.2, 56.

20. A.S.Joshi, A. Tiwari, Energy and exergy efficiencies of a hybrid photovoltaic-thermal (PV/T) air collector, Renewable Energy 32(13):2223-2241 · October 2007.

21. Akash kumar shukla, K.Shudhakar, P Baredra, Exergetic analysis of building integrated semitransparent photovoltaic module in clear sky condition at Bhopal India, Case Studies in Thermal Engineering 8 (2016) 142151. 